\title{
Minimal Invasive Radioguided Ectopic Parathyroidectomy in Upper Mediastinum
}

\author{
Üst Mediastinal Paratiroid Adenomunun Gamma Prob ile Minimal Invaziv Eksizyonu
}

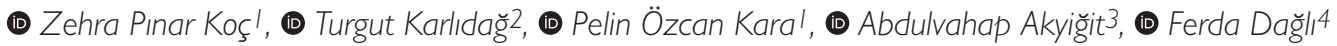 \\ IMersin University Faculty of Medicine, Department of Nuclear Medicine, Mersin, Turkey \\ 2Firat University Faculty of Medicine, Department of Ear Nose and Throat, Elazı $\breve{g}$, Turkey

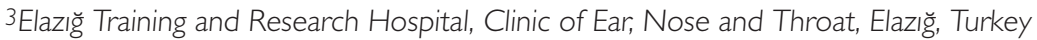 \\ ${ }^{4}$ Firat University Faculty of Medicine, Department of Pathology, Elazı $\breve{g}$, Turkey
}

\begin{abstract}
In this study we wanted to present a case with the history of multiple previous neck explorations and persisting upper mediastinal ectopic parathyroid adenoma who underwent a successful operation with radioguided minimal invasive approach.

Keywords: Hyperparathyroidism, adenoma, minimally invasive, radioimmunodetection
\end{abstract}

\section{Öz}

Bu çalışmada çok sayıda boyun operasyonu öyküsü ve kalıntı üst mediastinal ektopik paratiroid adenomu olan ve başarılı bir şekilde radyoişaretli minimal invaziv yaklaşımla opere edilen bir olguyu sunmak istedik.

Anahtar kelimeler: Hiperparatiroidizm, adenom, minimal girişimsel, radyoimmünotespit

Address for Correspondence: Zehra Pınar Koç MD, Mersin University Faculty of Medicine, Department of Nuclear Medicine, Mersin, Turkey Phone: +90 5305430579 E-mail: zehrapinarkoc@gmail.com ORCID ID: orcid.org/0000-0002-3274-5790 Received: 14.03.2016 Accepted: 17.03.2019

${ }^{\circ}$ Copyright 2019 by Turkish Society of Nuclear Medicine

Molecular Imaging and Radionuclide Therapy published by Galenos Yayınevi. 


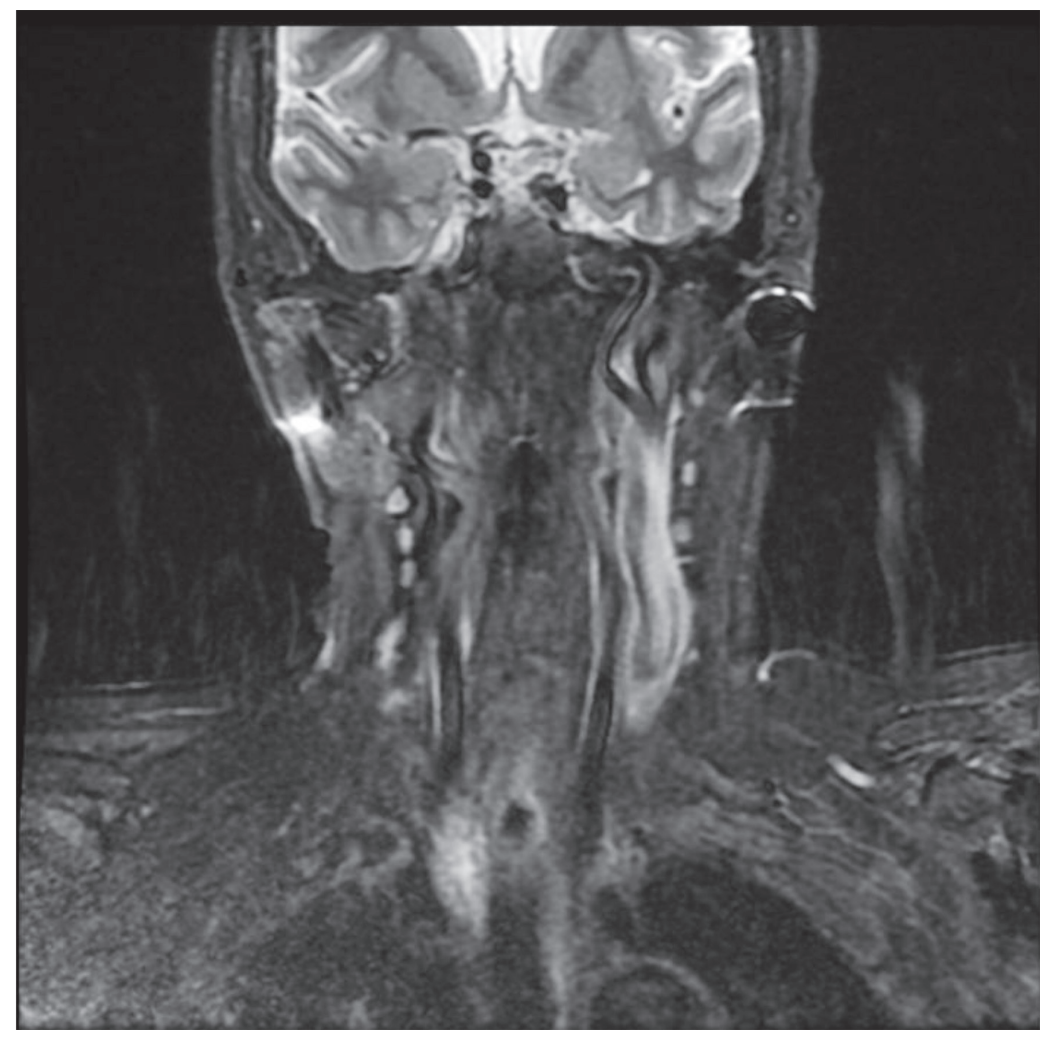

Figure 1. The magnetic resonance images showed remaining upper mediastinal parathyroid adenoma

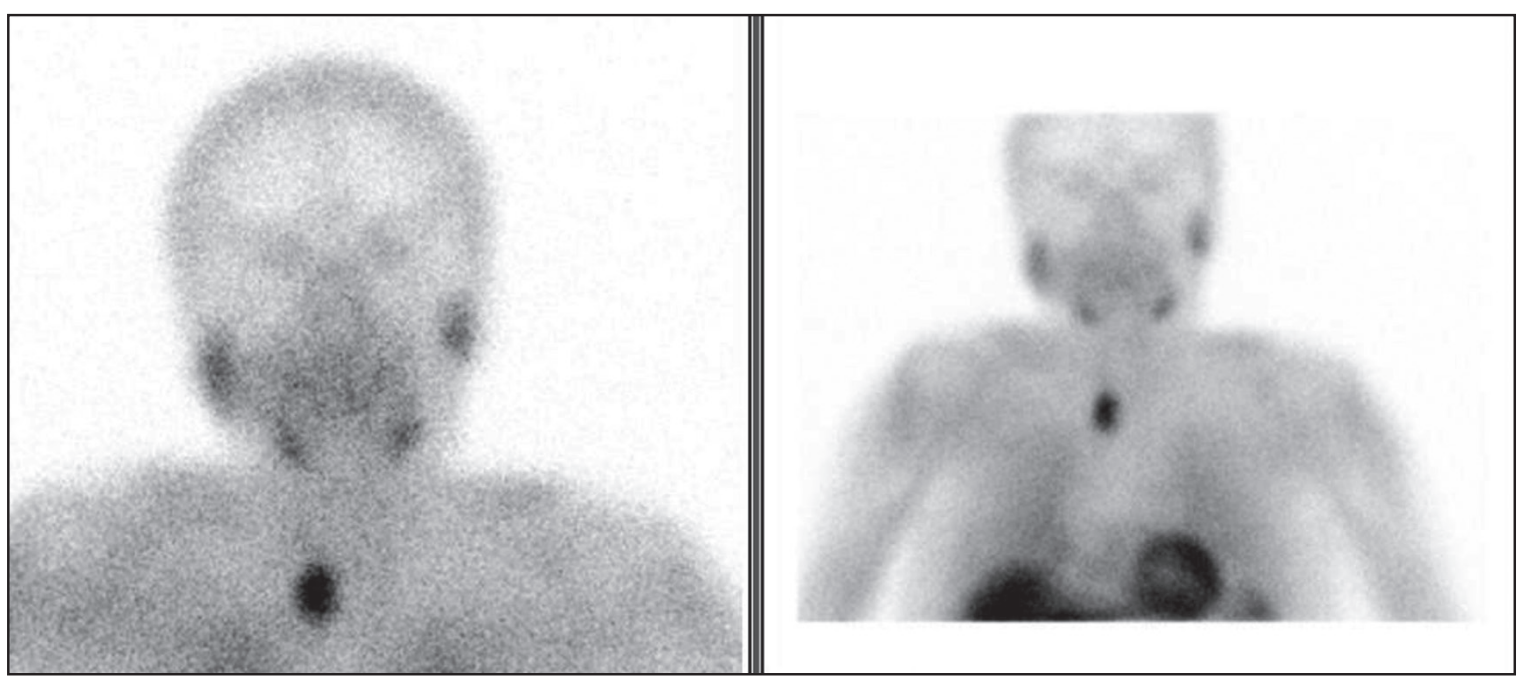

Figure 2. Anteroposterior early phase Tc-99m MIBI parathyroid planar image including the neck and mediastinum showing right upper mediastinal increased uptake consisted with the ectopic parathyroid adenoma. A 69-year-old female patient with the diagnosis of hyperparathyroidism; hypercalcemia and increased parathyroid hormone (PTH) levels and additional multinodular goiter was referred to our department for labeling for the radioguided surgery. The patient had anamnesis of bilateral total thyroidectomy due to multinodular goiter and an additional failed surgery for the parathyroid adenoma excision due to the ectopic localization of adenoma. She had previous diagnosis of incidental papillary microcarcinoma of the thyroid gland. Persistent hipercalcemia and hyperparathyroidism were observed after the two operative procedures. Parathyroid scintigraphy was performed by intravenous injection of $370 \mathrm{mBq}$ Tc-99m MIBI with low energy high resolution collimator equipped double head SPECT gamma camera prior to the surgery. The clear demonstration of a parathyroid adenoma in planar images obviated the need for SPECT imaging. The patient was 
referred to the operation after scintigraphy imaging for radioguided surgery with handheld gamma probe. In the operation room, the background count per minute (cpm) level was 5 from the shoulder and postoperative field count was 200 and the count of the lesion was $1500 \mathrm{cpm}$. The lesion was between the trachea and esophagus (retroesophageal) and the surgery was performed by a small incision of $2 \mathrm{~cm}$ wide. The lesion which was confirmed as a parathyroid adenoma by the pathology result was 2,704 gram in weight and $3 \times 1.6 \times 0.8 \mathrm{~cm}$ in size. Successful removal was confirmed both by postoperative counts and quick PTH analysis (preoperative: 698 pg/mg postoperative: 70.9 pg/mg (normal values: PTH 14-74 pg/mg). No complication was observed during or after the surgery. The patient was normocalcemic after six months of follow up. The definition of minimal invasive parathyroidectomy includes focused surgery planned for the excision of a single enlarged parathyroid gland (1). Routine parathyroid surgery includes inspection and exploration of all the neck, however in recent years the dissemination of imaging methods has contributed to development of this novel surgical approach (minimal invasive surgery) which is a targeted and secure way of successful surgery. Minimally invasive procedures are more comfortable for both the surgeon and the patient due to the cost effectiveness, being safe in terms of complications, and reduced operation, recovery and hospitalization times. Ectopic parathyroid adenoma is a diagnostic challenge which may be located in anywhere between angle of mandibule and mediastinum (2). Approximately $70 \%$ of the patients that have failed surgery are due to the ectopic localization of the parathyroid adenoma (3). Most of the upper mediastinal lesions might be excised by a cervical incision (4). However, preoperative localization methods are necessary for successful result (5). Currently the most accurate and reliable method for the localization of the parathyroid adenoma is the parathyroid scintigraphy with additional ultrasonography. Planar parathyroid scintigraphy achieves a sensitivity of 78\% and with additional SPECT imaging this ratio increases to $96 \%$ according to the previous reports (6). There is limited number of reports of the radioguided surgery for mediastinal lesions. In a previous report, Doğan et al. (7) considered gamma probe as a useful method for ectopic parathyroid adenoma operation. Also in a previous series involving minimal invasive procedures of 102 patients, radioguided surgery was found to be an efficient method, especially in the upper mediastinal lesions (8). The reported patient in this study had a successful surgery and excellent outcome after her third operation without any complications. This case reports shows that minimal invasive radioguided surgery is also possible and required for the patients with history of multiple previous neck explorations and upper mediastinal lesions.

\section{Ethics}

Informed Consent: Obtained.

Peer-review: Externally peer-reviewed.

\section{Authorship Contributions}

Surgical and Medical Practices: Z.P.K., T.K., A.A., F.D., Concept: Z.P.K., T.K., A.A., Design: Z.P.K., T.K., A.A., Data Collection or Processing: Z.P.K., T.K., A.A., F.D., Analysis or Interpretation: Z.P.K., T.K., A.A., F.D., P.Ö.K., Literature Search: Z.P.K., T.K., A.A., F.D., P.Ö.K., Writing: Z.P.K., T.K., A.A., F.D., P.Ö.K.

Conflict of Interest: No conflict of interest was declared by the authors.

Financial Disclosure: The authors declared that this study received no financial support.

\section{References}

1. Noureldine SI, Gooi Z, Tufano RP. Minimally invasive parathyroid surgery. Gland Surg 2015;4:410-419.
2. Wang CA. Parathyroid re-exploration. A clinical and pathological study of 112 cases. Ann Surg 1977; 186:140-145.

3. Uludag M, Isgor A, Yetkin G, Atay M, Kebudi A, Akgun I. Supernumerary ectopic parathyroid glands. Persistent hyperparathyroidism due to mediastinal parathyroid adenoma localized by preoperative single photon emission computed tomography and intraoperative gamma probe application. Hormones (Athens) 2009;8:144-149.

4. Medrano C, Hazelrigg SR, Landreneau RJ, Boley TM, Shawgo T, Grasch A. Thoracoscopic resection of ectopic parathyroid glands. Ann Thorac Surg 2000;69:221-223.

5. Wang C, Gaz RD, Moncure AC. Mediastinal parathyroid exploration. A clinical and pathologic study of 47 cases. World J Surg 1986;10:687-695.

6. Harvey A, Bohacek L, Neumann D, Mihaljevic T, Berber E. Robotic thoracoscopic mediastinal parathyroidectomy for persistent hyperparathyroidism: case report and review of the literature. Surg Laparosc Endosc Percutan Tech 2011;21:24-27.

7. Doğan R, Kara M, Yazicioğlu A, Kaynaroğlu V. The use of gamma probe for the intraoperative localization of an ectopic parathyroid adenoma. Tuberk Toraks 2009;57:208-211.

8. Rubello D, Casara D, Giannini S, Piotto A, De Carlo E, Muzzio PC, Pelizzo MR. Importance of radio-guided minimally invasive parathyroidectomy using hand-held gamma probe and low (99m)Tc-MIBI dose. Technical considerations and long-term clinical results. Q J Nucl Med 2003;47:129138. 